удк 336.225

\title{
ТЕОРЕТИКО-ОРГАНІЗАЦІЙНІ ДОМІНАНТИ ПОДАТКОВОГО АДМІНІСТРУВАННЯ В СИСТЕМІ ДЕРЖАВНОГО ПОДАТКОВОГО МЕНЕДЖМЕНТУ
}

\section{THEORETICAL AND ORGANIZATIONAL DOMINANTS OF TAX ADMINISTRATION IN THE SYSTEM OF STATE TAX MANAGEMENT}

\author{
Сідельникова Лариса Петрівна \\ доктор економічних наук, профресор, \\ Херсонський національний технічний університет \\ ORCID: https://orcid.org/0000-0001-7182-2923 \\ Sidelnykova Larysa \\ Kherson National Technical University
}

Розглянуто теоретичні засади державного податкового менеджменту. Зроблено висновки щодо ключової ролі податкового адміністрування в системі державного податкового менеджменту. Досліджено генезис наукових підходів щодо трактування поняття «податкове адміністрування». Визначені його елементи 3 урахуванням положень чинного податкового законодавства. Узагальнено сучасний науковий доробок щодо теоретико-організаційних аспектів системи адміністрування податків, що дозволило сорормулювати авторські підходи до розуміння поняття «податкове адміністрування», його об'єкту, суб'єктів та фрункцій. Дана оцінка поточного стану податкового законодавства в Україні. Доведено, що акценти податкового адміністрування мають бути зміщені у бік розбудови партнерських взаємовідносин між Державною податковою службою України та платниками податків.

Ключові слова: податки, державний податковий менеджмент, податкове адміністрування, об'єкт, суб'єкт, фрункції, Податковий кодекс України.

Рассмотрены теоретические основы государственного налогового менеджмента. Сделаны выводы о ключевой роли налогового администрирования в системе государственного налогового менеджмента. Исследован генезис научных подходов к трактовке понятия «налоговое администрирование». Определены его элементы с учетом положений действующего налогового законодательства. Обобщены современные научные наработки касательно теоретико-организационных аспектов системы администрирования налогов, что позволило сорормулировать авторские подходы к пониманию понятия «налоговое администрирование», его объекта, субъектов и фрункций. Дана оценка текущего состояния налогового законодательства в Украине. Доказано, что акценты налогового администрирования должны быть смещены в сторону развития партнерских взаимоотношений между Государственной налоговой службой Украины и налогоплательщиками.

Ключевые слова: налоги, государственный налоговый менеджмент, налоговое администрирование, объект, субъект, функции, Налоговый кодекс Украины.

The theoretical principles of state tax management are considered, its purpose, tasks, object and subjects are defined in the article. It is proved that the main task of the state tax management is to ensure timely, complete and continuous implementation of fiscal and regulatory functions of taxes. The functional subsystems of the state tax management are defined as tax regulation (economic form) and tax administration (administrative form). It is emphasized that the key role in improving the state tax management is given to tax administration as an effective means of activating organizational and human factors in taxation. The genesis of scientific approaches to understanding the concept of "tax administration" is studied. Legislative formulation of tax administration, which is regulated by the Tax Code of Ukraine from the standpoint of practical implementation of functions by regulatory authorities, is given. A critical analysis and generalization of modern scientific research and publications on the theoretical and organizational dominants of the tax administration system are conducted, which allowed to formulate the author's approaches to understanding the concept of "tax administration". The elements of the tax administration system are determined taking into account the provisions of the current tax legislation. Scientific controversy regarding the definition of the 
object, subjects and functions of tax administration is given, their author's interpretation is offered. The sub-functions of the tax administration system are systematized, special attention is paid to the control sub-function. Conclusions on the current state of tax legislation in Ukraine are made. It is proved that the emphasis of tax administration should be shifted towards building partnerships between the State Tax Service of Ukraine and taxpayers, expanding the boundaries of tax administration from purely fiscal and control activities to constructive dialogue, creating fair tax conditions for legal entities and individuals, balancing interests and responsibilities of all participants in tax relations.

Keywords: taxes, state tax management, tax administration, object, subject, functions, Tax Code of Ukraine.

Постановка проблеми. Реалізація довгострокової економічної стратегії України в сучасних умовах посилення гібридних викликів на шляху до трансорормації у високорозвинену країну європейського типу, орієнтація на стале економічне зростання вимагають удосконалення сучасної діяльності держави у регулюванні макроекономічних процесів. Наразі податкова фрорма взаємовідносин держави та економічних суб'єктів стає провідною, тому ресрормування податкової системи України розглядається як один 3 головних напрямів підвищення ефеективності державної економічної політики.

Чільне місце при вдосконаленні державного податкового менеджменту відводиться податковому адмініструванню як дієвому засобу активізації організаційного та людського чинників в оподаткуванні. Модернізація організаційно-управлінського компоненту діяльності Державної податкової служби України потребує науково обґрунтованих підходів до створення справедливих умов оподаткування, підвищення якості справляння податків, упровадження досконалих технологій їх адміністрування.

Аналіз останніх досліджень і публікацій. Проблематика підвищення ефективності податкового адміністрування не $є$ новою для української наукової спільноти. Вагомий внесок у дослідження проблем адміністрування податків зробили В. Андрущенко, 3. Варналій, О. Данілов, О. Десятнюк, Ю. Іванов, О. Іванішина, А. Крисоватий, М. Крупка, В. Мельник, С. Онишко, К. Проскура, А. Соколовська, Л. Тарангул, В. Тропіна, К. Швабій та ін.

Виділення невирішених раніше частин загальної проблеми. Разом з тим, в Україні бракує системних досліджень, у центрі уваги яких перебували б науково-методологічні постулати податкового адміністрування в системі державного податкового менеджменту та практичні заходи щодо підвищення його есрективності в новітніх умовах поглиблення транссрормаційних змін.

Формулювання цілей статті (постановка завдання). Метою статті $€$ дослідження теоретико-організаційних аспектів податкового адміністрування в системі державного податкового менеджменту і фрормулювання авторських підходів до розуміння цього поняття, його об'єкту, суб'єктів та фрункцій.

Виклад основного матеріалу дослідження. В сучасній українській науковій літературі існує певний спектр десрініцій поняття «державний податковий менеджмент», який, на нашу думку, доцільно узагальнити визначенням, поданим В. Кміть і Г. Івах, котрі пропонують розуміти державний податковий менеджмент як сукупність загально-правових норм, правил, фрорм, способів і методів управління податковою системою держави з метою координації та вдосконалення всіх аспектів оподаткування й напрямів реалізації державної податкової політики [1, с. 311].

Причому, Н. Катрук виділяє два підходи до визначення поняття «державний податковий менеджмент»: процесний і системний. За процесного підходу, на думку науковця, об'єктом управління державного податкового менеджменту $є$ процес оподаткування в державі, за системного - податкова система держави [2, с. 52]. Своєю чергою, М. Тарасюк об'єктом державного податкового менеджменту визначає відносини, що виникають між державою, в особі спеціально уповноважених органів державної влади, та платниками податків [3, с. 4].

Обидва підходи ми вважаємо доречними і такими, що дають можливість трактувати суб'єктами державного податкового менеджменту державу в особі відповідних інституцій (Верховна Рада України, Кабінет Міністрів України, Міністерство фрінансів України, Державна податкова служба України, Державна митна служба України, місцеві органи самоврядування) та платників податків (юридичних і фрізичних осіб).

Метою державного податкового менеджменту $€$ генерування ефективної реалізації завдань податкової політики держави. Основне його завдання полягає у забезпеченні своєчасного, повного і безперервного виконання податками фріскальної та регулюючої функцій.

Виходячи з мети та завдань державного податкового менеджменту, формами його здійснення, його функціональними підсис- 
темами О. Воронкова цілком обґрунтовано визначає податкове регулювання (економічна форма) та податкове адміністрування (адміністративна форма) [4, с. 58], причому адміністративні методи управління держава використовує для встановлення конкретних правил економічної поведінки для суб‘єктів податкових відносин, а також відповідальності за їх невиконання.

Отже, стисле узагальнення теоретичного доробку вітчизняної наукової думки дає можливість зробити висновки щодо ключової ролі податкового адміністрування в системі державного податкового менеджменту. Наше припущення підтверджує і теза А. Крисоватого, який обґрунтовує понятійно-категоріальний взаємозв'язок та, водночас, методологічні відмінності між цими поняттями: «державний податковий менеджмент - це, перш за все, важлива сорера методологічного забезпечення прийняття управлінських рішень, а податкове адміністрування - система науково обґрунтованих методичних дій щодо технічного регламентування та регулювання економічних відносин в оподаткуванні [5, с. 220]. Враховуючи зазначене, дослідження теоретико-організаційних домінант податкового адміністрування в умовах трансорормаційних змін вітчизняного фріскального простору не втрачає актуальності.

В Україні перші наукові праці з питань адміністрування податків почали з'являтися лише у другій половині 90-х років XX ст. Однак, у цей період ще не були чітко визначені теоретикометодологічні та організаційно-правові засади фріскального і податкового адміністрування, тому деякі науковці ототожнювали ці поняття. У витоків розкриття сутності саме податкового адміністрування стояв В. Мельник, який у 2003 році трактував адміністрування податків як управлінську діяльність органів державної виконавчої влади, яка пов'язана з організацією процесу оподаткування та засновується на державних законодавчих і нормативних актах [6, с. 41]. Разом з тим, у цьому визначенні вчений, цілком доречно наголосивши на правовому регламентуванні організації процесу оподаткування, не вказав мети заданої управлінської діяльності, її взаємозв'язку 3 податковою політикою держави. У пізніших напрацюваннях українські дослідники врахували цей недолік і запропонували більш комплексні дефрініції цього поняття.

Так, К. Проскура тлумачить податкове адміністрування як нормативно регламентовану організаційно-розпорядчу діяльність повноважних державних органів у сорері управління процесами оподаткування 3 метою забезпечення виконання вимог податкового законодавства учасниками податкових відносин [7, с. 54]. Разом з тим, у визначенні мети податкового адміністрування автор не акцентує увагу на її фріскальному та регулюючому аспектах, однак продовжує дослідження тезою, що «метою податкового адміністрування $€$ організація управлінсько-розпорядчого процесу у сорері оподаткування, який спрямовано на повноцінну реалізацію фрункцій податків, передусім забезпечення податкових надходжень у належних обсягах та належні строки, а також підтримку практичного регулювання окремих економічних явищ і процесів з урахуванням завдань державної соціально-економічної політики» [7, с. 55], що, на наш погляд, доцільно було б поєднати у авторському трактуванні поняття «податкове адміністрування».

Ю. Гусак у монографрії «Податкова політика України: стан, проблеми та перспективи» стверджує, що податкове адміністрування це логічно вибудований, науково обґрунтований процес державного управління податковими відносинами, направлений на максимізацію фрункції суспільного добробуту при умові виконання заданого бюджетного обмеження [8, с. 237]. Вважаємо такий підхід не повною мірою коректним, адже державні інституції, задіяні в процесі адміністрування податків, забезпечують своєчасний та безперервний рух податкових надходжень до бюджетів всіх рівнів, а максимізація срункції суспільного добробуту через раціональне та есрективне витрачання бюджетних ресурсів $€$ завданням інших державних органів.

О. Дубовик та О. Любчик звужують десрініцію «адміністрування податків» до безпосереднього виконання своїх фрункцій контролюючими органами, визначаючи його як комплекс взаємопов'язаних дій фріскальних органів, спрямованих на організацію податкового процесу та здійснення контролю над дотриманням податкового законодавства, правильністю обчислення, повнотою та своєчасністю сплати до бюджету податків, зборів та інших обов'язкових платежів [9, с. 72], що, на нашу думку, не дає можливості розкрити повною мірою змістовне навантаження цього поняття. В. Савчук, навпаки, надто розширює розуміння терміну «адміністрування податків», пропонуючи визначати його як управлінську діяльність держави у ссрері обґрунтування і розробки податкової політики, 
організації процесу оподаткування та забезпечення своєчасної і повної сплати податків і зборів платниками податків [10]. Вважаємо, що таке визначення більш доцільно застосовувати для тлумачення поняття «державний податковий менеджмент», фрункціональними підсистемами якого, як зазначалося вище, $€$ податкове регулювання та податкове адміністрування.

Низка авторів при трактуванні десрініції «податкове адміністрування» робить наголос на фріскальних наслідках такої діяльності, залишаючи поза увагою регулюючі аспекти есрективного адміністрування податків, що, на нашу думку, $\epsilon$ не повною мірою коректним. Так, А. Крисоватий і Т. Томнюк тлумачать адміністрування податків як сукупність взаємопов'язаних управлінських процедур, операцій та фрункцій прикладного характеру, які виконують органи виконавчої влади в безперервному циклічному процесі реалізації податкової політики держави з метою забезпечення мобілізації податків і податкових платежів до централізованих фондів грошових коштів держави та органів місцевого самоврядування [11, с. 42]. О. Воронкова переконує, що податкове адміністрування доцільно визначити як адміністративну діяльність, пов'язану із забезпеченням реалізації обов'язків і прав суб'єктів податкових відносин у процесі справляння податкових платежів з метою повного та своєчасного погашення податкових зобов'язань, з одного боку, і виконанням бюджетних завдань щодо податкових надходжень - 3 іншого [4, с. 56]. О. Іванішина та Ю. Панура розуміють податкове адміністрування як сукупність дій та рішень публічних владних структур, за допомогою яких, дотримуючись правових норм, фрінансові ресурси платників стягуються до централізованих фрінансових фондів (центрального або місцевих бюджетів) через механізм оподаткування внаслідок ухвалення та реалізації виважених і адекватних рішень компетентних державних органів (законодавчо-представницьких, виконавчих, судових) [12, с. 161].

Узагальнення та критичний аналіз сучасного доробку українських науковців щодо дослідження теоретичних постулатів податкового адміністрування дозволили ссрормулювати авторський підхід до розуміння цього поняття. Отже, на нашу думку, податкове адміністрування - це адміністративна діяльність відповідних державних інституцій в процесі управління податковими відносинами в державі $з$ метою своєчасної, повної і безпе- рервної мобілізації податкових надходжень до бюджетів всіх рівнів, а також забезпечення стимулюючих і дестимулюючих важелів податкового регулювання економічних процесів з урахуванням стратегічних та поточних завдань державної соціально-економічної політики.

Податковий кодекс України визначає податкове адміністрування 3 позиції практичної реалізації своїх фрункцій контролюючими органами, трактуючи його як сукупність рішень та процедур контролюючих органів і дій їх посадових осіб, що визначають інституційну структуру податкових та митних відносин, організовують ідентисрікацію, облік платників податків і платників єдиного внеску та об'єктів оподаткування, забезпечують сервісне обслуговування платників податків, організацію та контроль за сплатою податків, зборів, платежів відповідно до порядку, встановленого законом [13].

Отже, елементами податкового адміністрування з урахуванням положень чинного податкового законодавства пропонуємо вважати такі: організацію податкових відносин між контролюючими органами і платниками податків; прогнозування та планування податкових надходжень; облік платників податків; облік податкових надходжень; контрольноперевірочну роботу; управління податковими ризиками; роботу з податковим боргом; розгляд апеляційних скарг платників податків; масово-роз'яснювальну і консультативну роботу; розробку і впровадження електронних сервісів.

Зазначимо, що система адміністрування податків, як і кожна система управління, складається 3 двох взаємопов'язаних складових - суб'єкта управління (керуючої системи) та об'єкта управління (керованої системи).

Суб'єктами податкового адміністрування $€$, з одного боку, органи виконавчої влади загальної і спеціальної компетенції, судові та юрисдикційні органи, з іншого - платники податків (юридичні та фрізичні особи). В цьому контексті, А. Крисоватий і Т. Томнюк цілком доречно акцентують увагу на тому, що в управлінських процесах оподаткування суб'єкти перебувають у неоднаковому положенні $[11$, с. 43]. Погоджуємося з такою думкою, адже державні інституції, що забезпечують реалізацію процесів податкового адміністрування, володіють владними повноваженнями, які дозволяють їм реалізовувати свої компетенції, натомість, платники податків в якості повноважень мають лише правоздатність юридичної або фрізичної 
особи. Тобто, держава в особі відповідних інституцій ухвалює рішення, які для платників податків є обов'язковими для виконання.

Зазначене твердження $€$ важливим і для розуміння соціальної адаптації системи адміністрування податків. Так, В. Андрущенко підкреслює, що у центрі системи знань про податкове адміністрування перебувають не самі податки, а люди як «суб'єкти мотивацій, процедур, технологій профресійної діяльності... у прийнятті рішень, збиранні податків і здійсненні податкової політики» [14, с. 28]. Тобто, на думку вченого, яку ми підтримуємо, інструментарій податкового адміністрування дозволяє дослідити поведінку і мотивації індивідів (фрізичних осіб) або їх спільнот (юридичних осіб), а також вивчити дії та рішення конкретних суб'єктів податкових відносин.

Щодо об'єкту податкового адміністрування єдиний науковий підхід в Україні наразі відсутній. Так, К. Проскура трактує об'єкт податкового адміністрування як податкові надходження (у вигляді податків, зборів, інших обов'язкових платежів) до бюджетів усіх рівнів [15, с. 65]; так само розуміє це поняття і М. Петричко [16, с. 135]. Подібне тлумачення об'єкта податкового адміністрування пропонують В. Хомутенко, І. Луценко, А. Хомутенко: «Об'єктом адміністрування $€$ податки, збори, митні платежі, єдиний соціальний внесок та інші обов'язкові платежі» [17, с. 15]. Разом з тим, вищенаведені фрормулювання, на нашу думку, є доволі спрощеним розумінням цієї дефрініції та не розкривають повною мірою її сутності.

В свою чергу, низка українських дослідників поглиблює трактування об'єкту адміністрування податків, розуміючи його як:

а) процес (мобілізації податкових платежів у бюджет [18, с. 219]; узгодження й погашення податкових зобов'язань платників податків [19]) або процеси (що відбуваються у зв'язку 3 виникненням, зміною та припиненням обов'язків щодо сплати податків і податкових платежів [11, с. 43]);

б) грошові відносини (що виникають між державою, з одного боку, і юридичними та фрізичними особами, 3 іншого боку, 3 приводу повної мобілізації податкових доходів до бюджетної системи і есрективного розподілу національного доходу) [20, с. 13];

в) розпорядчо-виконавчу діяльність владних політичних структур (щодо організації оподаткування і мистецтва управління податковою системою шляхом добровільного, а в необхідних випадках і примусового справляння податків у поєднанні з виховними діями морально- етичного характеру, а також роз'яснювальними і контрольними заходами) [14, с. 28].

Цікавим вбачаємо підхід В. Савчука, який відокремлює поняття «об'єкт адміністрування податків» (як стан нарахування і сплати податків до бюджету) та «об'єкт адміністрування податкових зобов'язань» (як процес узгодження і погашення податкових зобов'язань платників податків) [10]. Водночас, на нашу думку, таке розмежування певною мірою обтяжує понятійно-категоріальний апарат фрінансової науки.

Узагальнюючі ці та інші наукові підходи до розуміння зазначеної дефініції, вважаємо за доцільне трактувати об'єктом податкового адміністрування процеси, що супроводжують виникнення, зміни та припинення обов'язків щодо сплати податків і податкових платежів в процесі мобілізації податкових надходжень до бюджетів всіх рівнів та забезпечення важелів податкового регулювання економічних процесів.

Сутність податкового адміністрування проявляється через фрункції, що безпосередньо впливають на реалізацію процесу адміністрування. Виходячи 3 того, що у фрінансовій науці фрункції завжди похідні від сутності, яку вони виражають, та ілюструють, у який спосіб реалізується суспільне призначення даної економічної категорії, основні фрункції податкового адміністрування, на наше переконання, $€$ тотожними фрункціям податків - фріскальній та регулюючій. Причому фріскальна срункція податкового адміністрування зумовлює мету адміністрування в частині фрормування бюджетних ресурсів держави; регулююча спрямована на вирішення за допомогою механізмів адміністрування завдань державної соціально-економічної політики.

Разом з тим, доволі розгалуженим є спектр підфрункцій, які відображають діяльність контролюючих органів в процесі податкового адміністрування, а саме: організаційно-розпорядча, аналітична, планування й прогнозування, облікова, координаційна, контрольна, управління ризиками, апеляційна, роз'яснювальна та консультативна, інформаційна.

Зазначимо, що деякі українські науковці акцентують увагу саме на контрольній підфрункції податкового адміністрування, виводячи ії на рівень окремої фрункції $[17$, с. 16 ; 18, с. $218 ; 20$, с. 13]. На нашу думку, доцільно зробити припущення, що таке бачення срункцій податкового адміністрування ґрунтується на традиційному трактуванні переліку фрункцій категорії «фрінанси», де контрольна фрунк- 
ція відіграє одну з основних ролей. Натомість, ми не можемо погодитися 3 таким підходом, адже розглядаємо систему адміністрування податків крізь призму теоретико-методологічних підходів до розуміння категорії «податок» та дотримуємося думки щодо виконання податками, а відповідно і податковим адмініструванням, двох фрункцій - фріскальної та регулюючої. Разом 3 тим, підкреслимо, що контрольна підфункція, яка проявляється у податковому контролі шляхом проведення податковими органами контрольно-перевірочної роботи, діє не ізольовано, вона тісно пов'язана 3 основними ффункціями податкового адміністрування.

Висновки. Підсумовуючи, зазначимо, що у вітчизняному фріскальному просторі фрункціонування системи адміністрування податків, зборів і платежів регулюється Розділом II Податкового кодексу України [13]. Однак, на жаль, цей основний податковий законодавчий акт характеризується нестабільністю та наявністю різного роду фрлуктуацій. Впродовж періоду його чинності зміни і доповнення вносилися до всіх розділів Кодексу, жоден 3 аспектів фрункціонування податкової системи, у тому числі в частині механізму податкового адміністрування, не залишився без коригувань. Перша редакція Кодексу взагалі не передбачала визначення поняття адміністрування податків - відповідний пп. 14.1.11 п. 14.1 ст. 14 з'явився лише у липні 2013 року.

Наприкінці 2014 року Податковий кодекс України кардинально трансформовано, істотно скорочено кількість податків і зборів, змінено механізми справляння окремих податків, уточнено процедури податкового адміністрування. Вже у 2016 році очікувалося прийняття основного законодавчого акту країни у ссрері оподаткування у новій редакції, однак втілення рефрорми податкової системи України через коригування положень Податкового кодексу перебуває у стадії обговорення дотепер.

Разом з тим, сучасні транссрормаційні процеси соціально-економічного розвитку України в контексті європейської інтеграції і розбудови демократичного суспільства конче вимагають реформування всіх складових податкової системи, у тому числі податкового адміністрування, акценти якого мають бути зміщені у бік розбудови партнерських взаємовідносин між Державною податковою службою України та платниками податків, розширення меж адміністрування податків із суто фріскальної і контролюючої діяльності до конструктивнодіалогової, створення справедливих умов оподаткування для юридичних та фрізичних осіб, збалансування інтересів та відповідальності всіх учасників податкових відносин.

Перспективи подальших розвідок у даному напрямі передбачають перехід від дослідження теоретико-організаційних аспектів податкового адміністрування до практичних заходів щодо підвищення його есрективності в Україні через розробку сучасних механізмів адміністрування податків, адаптованих до європейських стандартів, з метою сприяння підвищенню добровільності сплати податків; унеможливлення проявів корупції в податкових відносинах; акумуляції обсягу бюджетних ресурсів держави, достатнього для забезпечення сталого соціально-економічного розвитку.

\section{СПИСОК ВИКОРИСТАНИХ ДЖЕРЕЛ:}

1. Кміть В.М., Івах Г.В. Роль податкового регулювання в системі державного податкового менеджменту України. Актуальні проблеми розвитку економіки регіону. 2011. Вип. 7(2). С. 310-316.

2. Катрук Н.О. Обґрунтування сутності державного податкового менеджменту в контексті становлення наукової думки. Наука й економіка. 2010. № 2(18). С. 47-55.

3. Тарасюк М.В. Теоретичні засади державного податкового менеджменту. Сталий розвиток економіки. 2013. № 3(20). C. 3-8.

4. Воронкова О.М. Система державного податкового менеджменту: сутність, склад, особливості. Вісник Донецького національного університету. Серія : Економіка і право. 2013. Вип. 2. С. 54-58.

5. Крисоватий А.І. Теоретико-організаційні домінанти та практика реалізації податкової політики в Україні : монографія. Тернопіль : Карт-бланш, 2005. 372 с.

6. Мельник В.М. Проблеми теорії та практики адміністрування податків в Україні. Актуальні проблеми економіки. 2003. № 5(23). С. 40-43.

7. Проскура К.П. Особливості адміністрування податків в Україні. Економічний часопис - XXI. 2012. № 3-4. C. 53-55.

8. Податкова політика України: стан, проблеми та перспективи : монографрія / П.В. Мельник, Л.Л. Тарангул, 3.С. Варналій та ін.; за ред. 3.С. Варналія. Київ : Знання України, 2008. 657 с. 
9. Дубовик О.Ю., Любчик О.К. Розвиток податкового механізму адміністрування в Україні. Причорноморські економічні студії. 2018. Вип. 36. С. 71-75.

10. Савчук В.А. Теоретичні засади організації адміністрування податків. Ефрективна економіка : електронний журнал. 2013. № 3. URL: http://www.economy.nayka.com.ua/?op=1\&z=1852

11. Крисоватий А.І., Томнюк Т.Л. Адміністрування податків в Україні: організація та напрями транссормації : монографрія. Тернопіль : Економічна думка ТНЕУ, 2012. 212 с.

12. Іванішина О.С., Панура Ю.В. Економічний зміст податкового адміністрування. Науковий вісник Мукачівського державного університету. Серія «Економіка». 2018. Вип. 1(9). С. 159-163.

13. Податковий кодекс України : Закон України від 02.12.2010 р. № 2755-VI. Дата оновлення: 17.12.2020. URL: https://zakon.rada.gov.ua/laws/show/2755-17

14. Андрущенко В.Л. Фіскальне адміністрування як наука і мистецтво. Фінанси України. 2003. № 6. С. 27-35.

15. Проскура К.П. Податкове адміністрування в Україні в посткризовий період: есрективність та напрями модернізації : монографрія. Київ : Емкон, 2014. 376 с.

16. Петричко М.М. Сучасний стан адміністрування податків і зборів в Україні. Науковий вісник Херсонського державного університету. Серія : Економічні науки. 2016. Вип. 16. Част. 2. С. 133-135.

17. Хомутенко В.П., Луценко І.С., Хомутенко А.В. Адміністрування податків, зборів, платежів : навч. посіб. I за заг. ред. В.П. Хомутенко. Одеса : Атлант, 2015. 314 с.

18. Крупка М.І., Кміть В.М., Паславська Р.Ю. Система адміністрування податків в Україні: стан, проблеми та перспективи. Науковий вісник НЛтУ України. 2016. Вип. 26.2. С. 217-224.

19.Бойко О. Ефрективність системи податкового адміністрування в Україні. Демократичне врядування : періодичне електронне видання. 2017. Вип. 20. URL: http://lvivacademy.com/vidavnitstvo_1/visnyk20/fail/Bojko.pdf

20. Ясько І.В. Теоретико-правові засади податкового адміністрування в Україні : авторефр. дис. ... канд. юр. наук : 12.00.07. Львів, 2019. 20 с.

\section{REFERENCES:}

1. Kmit V.M., Ivakh H.V. (2011) Rol podatkovoho rehuliuvannia v systemi derzhavnoho podatkovoho menedzhmentu Ukrainy [The role of tax regulation in the system of state tax management of Ukraine]. Aktualni problemy rozvytku ekonomiky rehionu, vol. 7(2), pp. 310-316.

2. Katruk N.O. (2010) Obgruntuvannia sutnosti derzhavnoho podatkovoho menedzhmentu v konteksti stanovlennia naukovoi dumky [Substantiation of the essence of state tax management in the context of the formation of scientific thought]. Nauka y ekonomika, no. 2(18), pp. 47-55.

3. Tarasiuk M.V. (2013) Teoretychni zasady derzhavnoho podatkovoho menedzhmentu [Theoretical principles of state tax management]. Stalyi rozvytok ekonomiky, no. 3(20), pp. 3-8.

4. Voronkova O.M. (2013) Systema derzhavnoho podatkovoho menedzhmentu: sutnist, sklad, osoblyvosti [The system of state tax management: essence, composition, features]. Visnyk Donetskoho natsionalnoho universytetu. Seriia: Ekonomika i pravo, vol. 2, pp. 54-58.

5. Krysovatyi A.I. (2005) Teoretyko-orhanizatsiini dominanty ta praktyka realizatsii podatkovoi polityky v Ukraini [Theoretical and organizational dominants and practice of tax policy implementation in Ukraine]. Ternopil: Kartblansh (in Ukrainian).

6. Melnyk V.M. (2003) Problemy teorii ta praktyky administruvannia podatkiv v Ukraini [Problems of theory and practice of tax administration in Ukraine]. Aktualni problemy ekonomiky, no. 5(23), pp. 40-43.

7. Proskura K.P. (2012) Osoblyvosti administruvannia podatkiv v Ukraini [Features of tax administration in Ukraine]. Ekonomichnyi chasopys - XXI, no. 3-4, pp. 53-55.

8. Melnyk P.V., Taranhul L.L., Varnalii Z.S., etc. (2008) Podatkova polityka Ukrainy: stan, problemy ta perspektyvy [Tax policy of Ukraine: state, problems and prospects]. In Z.S. Varnalii (Ed.). Kyiv: Znannia Ukrainy. (in Ukrainian)

9. Dubovyk O.Yu., Liubchyk O.K. (2018) Rozvytok podatkovoho mekhanizmu administruvannia v Ukraini [Development of the tax mechanism of administration in Ukraine]. Prychornomorski ekonomichni studii, vol. 36, pp. 71-75.

10. Savchuk V.A. (2013) Teoretychni zasady orhanizatsii administruvannia podatkiv [Theoreti-
[ cal bases of the organization of tax administration]. Efektyvna ekonomika: elektronnyi zhurnal, no. 3. URL: http://www.economy.nayka.com.ua/?op=1\&z=1852

11. Krysovatyi A.I., Tomniuk T.L. (2012) Administruvannia podatkiv v Ukraini: orhanizatsiia ta napriamy transformatsii [Tax administration in Ukraine: organization and directions of transformation]. Ternopil: Ekonomichna dumka TNEU. (in Ukrainian)

12. Ivanishyna O.S., Panura Yu.V. (2018) Ekonomichnyi zmist podatkovoho administruvannia [Economic content of tax administration]. Naukovyi visnyk Mukachivskoho derzhavnoho universytetu. Seriia: Ekonomika, vol. 1(9), pp. 159-163. 
13. Podatkovyi kodeks Ukrainy: Zakon Ukrainy vid 02.12.2010 r. № 2755-VI. URL: https://zakon.rada.gov.ua/ laws/show/2755-17

14. Andrushchenko V.L. (2003) Fiskalne administruvannia yak nauka i mystetstvo [Fiscal administration as a science and art]. Finansy Ukrainy, no. 6, pp. 27-35.

15. Proskura K.P. (2014) Podatkove administruvannia v Ukraini v postkryzovyi period: efektyvnist ta napriamy modernizatsii and directions [Tax administration in Ukraine in the post-crisis period: efficiency of modernization]. Kyiv: Emkon. (in Ukrainian)

16. Petrychko M.M. (2016) Suchasnyi stan administruvannia podatkiv i zboriv v Ukraini [The current state of administration of taxes and fees in Ukraine]. Naukovyi visnyk Khersonskoho derzhavnoho universytetu. Seriia: Ekonomichni nauky, vol. 16, part 2, pp. 133-135.

17. Khomutenko V.P., Lutsenko I.S., Khomutenko A.V. (2015) Administruvannia podatkiv, zboriv, platezhiv [Administration of taxes, fees, payments]. In V.P. Khomutenko (Ed.). Odesa: Atlant. (in Ukrainian)

18. Krupka M.I., Kmit V.M., Paslavska R.Yu. (2016) Systema administruvannia podatkiv v Ukraini: stan, problemy ta perspektyvy [The system of tax administration in Ukraine: status, problems and prospects]. Naukovyi visnyk NLTU Ukrainy, vol. 26.2, pp. 217-224.

19. Boiko O. (2017) Efektyvnist systemy podatkovoho administruvannia $v$ Ukraini [Efficiency of the tax administration system in Ukraine]. Demokratychne vriaduvannia: periodychne elektronne vydannia, vol. 20. URL: http://lvivacademy.com/vidavnitstvo_1/visnyk20/fail/Bojko.pdf

20. Yasko I.V. (2019) Teoretyko-pravovi zasady podatkovoho administruvannia v Ukraini [Theoretical and legal principles of tax administration in Ukraine]. Extended abstract of Candidate's thesis. Lviv. (in Ukrainian) 